\title{
TRADISI APPAKASINGERA'DALLE (STUDI KASUS PADA MASYARAKAT DESA BUNGAEAYAJA KABUPATEN GOWA)
}

\author{
Asmarani Umar ${ }^{1 *}$, Idham Irwansyah ${ }^{2}$ \\ ${ }^{1}$ Mahasiswa Jurusan Sosiologi Fakultas Ilmu Sosial \\ Universitas Negeri Makassar \\ Email: asmaraniumar@gmail.com \\ ${ }^{2}$ Dosen Sosiologi/ Universitas Negeri Makkassar \\ Email:idham.irwansyah@unm.ac.id
}

\begin{abstract}
ABSTRAK
Penelitian ini bertujuan untuk mengetahui dan memahami bertahannya tradisi appakasingera' dalle sampai sekarang, dan nilai-nilai sosial yang terkandung di dalam tradisi appakasingera' dalle. Teori yang digunakan adalah teori solidaritas, teori tindakan sosial (tindakan tradisional), nilai dan tradisi. Penelitian ini menggunakan metode kualitatif dengan pendekatan studi kasus dan mengambil lokasi penelitian di Desa Bungaejaya kecamatan Pallangga Kabupaten Gowa. Teknik pengambilan informan yang digunakan adalah purposive sampling yaitu memilih data informan berdasarkan karakteristik yang telah ditetapkan. Teknik pengumpulan data yang digunakan yaitu observasi, wawancara dan dokumentasi. Teknik analisis data kualitatif deskriptif yang digunakan yaitu reduksi data, penyajian data, dan kesimpulan. Hasil penelitian menunjukkan bahwa masyarakat Desa Bungaejaya masih tetap menjalankan dan mempertahankan tradisi appakasingera' dalle sampai sekarang karena adanya penanaman history atau sejarah dan proses pelaksanaan tradisi sejak dini dilakukan oleh para pendahulu mereka, selain itu adanya nilai-nilai yang terkandung di dalam tradisi, yang membuat masyarakat Bungaejaya menjadikannya sebuah dasar untuk tetap mempertahankan tradisinya. Selanjutnya adanya nilai- nilai sosial didalam tradisi appakasingera' dalle yaitu: nilai solidaritas, nilai kepedulian sosia, dan nilai spiritual.
\end{abstract}

Kata kunci: tradisi, appakasingera' dalle, masyarakat

\begin{abstract}
This study aims to determine and understand the persistence of the appakasingera 'dalle tradition until now, and the social values contained in the appakasingera' dalle tradition. The theories used are solidarity theory, social action theory (traditional action), values and traditions. This study used a qualitative method with a case study approach and took the research location in Bungaejaya Village, Pallangga District, Gowa Regency. The informant retrieval technique used was purposive sampling, namely selecting informant data based on predetermined characteristics. The data collection techniques used were observation, interview and documentation. The descriptive qualitative data analysis technique used is data reduction, data presentation, and conclusion. The results showed that
\end{abstract}


the people of Bungaejaya Village still carry out and maintain the appakasingera 'dalle tradition until now because of the cultivation of history or history and the process of carrying out the tradition from an early age by their predecessors, besides that there are values contained in the tradition, which make Bungaejaya people make it a basis for maintaining its traditions. Furthermore, there are social values in the appakasingera 'dalle tradition, namely: solidarity values, social care values, and spiritual values.

Keywords: tradition, appakasingera 'dalle, society

\section{PENDAHULUAN}

Tercipta atau terwujudnya suatu kebudayaan adalah sebagai hasil interaksi antara manusia dengan segala isi alam raya ini, dalam hal ini kebudayaan tidak lain adalah semua hasil karya, rasa, dan cipta manusia, dengan sumber-sumber kemampuan atau potensi manusia tersebut, nyatalah bahwa manusia menciptakan kebudayaan. Ada hubungan dialektika antara manusia dan kebudayaan dengan kata lain, kebudayaan ada karena ada manusia sebagai penciptanya dan manusia dapat hidup di tengah kebudayaan yang diciptakannya. Kebudayaan akan terus hidup manakala ada manusia sebagai pendukungnya. Perilaku manusia yang berkembang pada suatu masyarakat yang dilakukan oleh manusia secara terus menerus pada akhirnya akan menjadi tradisi.

Tradisi ini merupakan suatu kebiasaan baik berupa tindakan maupun tuturan yang dilakukan oleh suatu masyarakat pada suatu daerah tertentu serta diwarisi secara turun temurun. Tradisi yang dianggap oleh masyarakat pendukungnya masih bernilai positif akan terus dipertahankan, sementara tradisi yang dianggap tidak sesuai lagi dengan perkembangan zaman atau zaman modern, dimana kehidupan persaingan didalamnya berjalan begitu ketatnya, sehingga tradisi yang sudah tidak sesuai lagi akan ditinggalkan oleh pendukungnya.

Tidak bisa dipungkiri bahwa di tengah kehidupan globalisasi seperti sekarang ini masih banyak tradisi diberbagai daerah di Indonesia yang masih terus di pertahankan keberadaannya, hal itu tentunya karena tradisi tersebut masih dibutuhkan dan masih dianggap bernilai positif karena mengandung makna-makna yang masih sangat dibutuhkan dalam menjalani kehidupan sekarang.

Seperti halnya tradisi appakasingera' dalle. Istilah appakasingera' dalle berasal dari bahasa Makassar kuno, yang di mana kata appakasingera' berarti "penerang" dan kata dalle yang berarti "rejeki". Tradisi appakasingera' dalle merupakan suatu tradisi atau adat istiadat yang secara turun-temurun telah dilakukan oleh masyarakat Desa Bungaejaya Kecamatan Pallangga Kabupaten Gowa setelah sekian lama. Desa Bungaejaya merupakan suatu desa yang duluya juga disebut sebagai Kampung Daeng, yang jaraknya $\pm 7 \mathrm{~km}$ dari kota Gowa. Populasi masyarakat di desa Bungaejaya berjumlah 4.496 orang. Pada umumnya masyarakat di sana ada yang berprofesi sebagai petani, buruh maupun peternak.

Dewasa ini, perlu diketahui bahwa di era modern seperti ini tradisi tersebut masih bertahan, padahal jika diamati dengan saksama sudah banyak pengaruh modernisasi yang masuk ke dalam lingkungan desa, yang memungkinkan untuk merubah pola pikir masyarakat. 
Menurut kepercayaan masyarakat desa, tradisi appakasingera' dalle ini merupakan suatu yang mistik atau disakralkan oleh masyarakat yang harus mereka kerjakan, dimana hal itu dapat mendatangkan ketenangan jiwa bagi mereka yang menjalankannya walaupun hidup mereka tidak berkecukupan. Konon kesakralan tradisi tersebut juga dikaitkan dengan datangnya suatu cahaya yang disaksikan oleh seorang Kadaengan (pemimpin) yang digelar sebagai Daengta Bungaejaya (orang yang dituakan di Bungaejaya). Daengta Bungaejaya merupakan seorang pemimpin desa pada waktu itu yang ketika pada masa keislaman di Gowa, ia diberi wahyu dan diminta untuk menyampaikannya kepada masyarakat desa tersebut bahwa hidup jangan hanya mencari rejeki tapi carilah berkah. Daengta Bungaejaya kemudian meminta kepada masyarakat agar setiap malam jumat mereka hendaknya menyalakan lilin, lalu ditaruh disudut pintu rumah mereka masing-masing, mulai menjelang Magrib hingga datangnya waktu shalat Isyah, hal ini dimaksudkan tidak lain untuk kepentingan masyarakat dan demi ketenangan dan kesejahteraan hidup masyarakat desa tersebut. Itulah yang menjadi awal dari di mulainya tradisi appakasingera' dalle tersebut.

\section{Rumusan Masalah}

Berdasarkan uraian diatas maka dapat ditemukan beberapa masalah yang dirumuskan sebagai berikut:

1. Mengapa tradisi appakasingera' dalle dapat bertahan sampai sekarang?

2. Nilai-nilai sosial apa yang terkandung di dalam tradisi appakasingera' dalle?

\section{Tujuan Penelitian}

1. Untuk mengetahui dan memahami tentang bertahannya tradisi tersebut sampai sekarang

2. Untuk mengetahui dan memahami nilai- nilai sosial yang terkandung didalam tradisi tersebut.

\section{Manfaat Penelitian}

Dari penelitian ini diharapkan dapat memberikan manfaat, diantaranya :

1. Untuk pengembangan akademik, diharapkan dapat dijadikan bahan pemikiran untuk penelitian selanjutnya.

2. Dapat menjadi bahan informasi bagi peneliti yang ingin mengadakan penelitian lebih lanjut sehubungan dengan tradisi appakasingera' dalle tersebut.

\section{Kerangka Konseptual}

Kebudayaan sangat erat hubungannya dengan masyarakat, dalam hal ini kebudayaan merupakan bagian dari tradisi atau perilaku manusia yang berkembang pada suatu masyarakat yang dilakukan oleh manusia secara terus menerus pada akhirnya akan menjadi tradisi, yang seperti halnya terjadi di Desa Bungaejaya Kecamatan Pallangga Kabupaten Gowa tersebut. Tradisi yang dilakukan seakan seperti mata rantai yang tak pernah putus dari satu generasi ke generasi lain.

Keberadaan dari tradisi tersebut tentunya mempunyai awal atau sejarah dari terciptanya suatu tradisi, hingga pada proses pelaksanaan yang tidak pernah mengalami perubahan sampai sekarang ini. Selain nilai-nilai sosial yang ada didalam tradisi tersebut seperti nilai solidaritas, nilai kepedulian sosial, dan nilai spiritual, inilah yang membuat masyarakat desa Bungaejaya masih tetap mempertahankan keberadaan atau eksistensi dari tradisinya. Menurut Polak (Setiadi, 2007:121), nilai dimaksudkan sebagai ukuran, patokan, anggapan, keyakinan yang dianut oleh orang luhur, dan baik untuk dikerjakan, dilaksanakan atau diperhatikan. Upe (2010:95-99), mengungkapkan jika solidaritas sosial menujuk pada suatu keadaan hubungan 
antara individu dan kelompok yang berdasarkan pada perasaan moral dan kepercayaan yang dianut bersama yang diperkuat oleh pengalaman emosional bersama.

Dukheim (Upe, 2010:95-99), membagi solidaritas menjadi dua bagian salah satunya adalah solidaritas mekanik. Solidaritas mekanik merupakan suatu tipe solidaritas yang didasarkan atas persamaan. Pada masyarakat dengan tipe solidaritas mekanik, individu diikat dalam suatu bentuk solidaritas yang memiliki kesadaran kolektif yang sama dan kuat. Karena itu individualitas tidak berkembang karena "dilumpuhkan" oleh tekanan besar untuk menerima konformitas. Melihat masyarakat Bungaejaya yang senantiasa secara bersamasama menjalankan dan tetap mempertahankan serta menjadikan tradisi appakasingera' dalle sebagai warisan leluhur yang tentunya harus mereka jaga dan hargai. Tipe solidaritas yang didasarkan atas kepercayaan dan kesetiakawanan ini diikat oleh apa yang dinamakan oleh Durkheim collective conscoiusness yaitu suatu sistem kepercayaan dan perasaan yang menyebar merata pada semua anggota masyarakat. Hal yang paling mendasar adalah adanya informasi yang diteruskan dari generasi ke generasi baik tertulis maupun (sering kali) lisan, karena tanpa adanya ini, suatu tradisi dapat punah. Tradisi atau kebiasaan sosial yang diturunkan dari satu generasi ke generasi lainnya ini tentunya melalui proses sosialisasi.

Proses di mana manusia berusaha menyerap isi kebudayaan yang berkembang ditempat kelahirannya. Dalam hal ini, bahwa proses inilah di mana generasi tua banyak menghabiskan waktunya untuk mentransmisikan kebudayaan kepada generasi penerusnya, dan generasi penerusnya biasanya banyak sekali menerima kesan dari berbagai upaya pengajaran tersebut. Menurut Weber (Johnson, 1986: 220-221), menjelaskan beberapa tipe-tipe tindakan sosial salah satunya adalah tindakan tradisional. Tindakan tradisional merupakan tipe tindakan sosial yang bersifat nonrasional. Kalau seorang individu memperlihatkan perilaku karena kebiasaan, tanpa refleksi yang sadar atau perencanaan, perilaku seperti itu digolongkan sebagai tindakan tradisional. Individu itu akan membenarkan atau menjelaskan tindakan itu kalau diminta, dengan hanya mengatakan bahwa dia selalu bertindak dengan cara seperti itu atau perilaku seperti itu merupakan kebiasaan baginya. Apabila kelompok-kelompok atau seluruh masyarakat didominasi oleh orientasi ini, maka kebiasaan dan institusi mereka diabsahkan atau didukung oleh kebiasaan atau tradisi yang sudah lama mapam sebagai kerangka acuannya, yang diterima begitu saja tanpa persoalan. Satu-satunya pembenaran yang perlu adalah bahwa" inilah cara yang sudah dilaksanakan oleh nenek moyang kami, dan demikian pula nenek moyang mereka sebelumnya; ini adalah cara yang sudah begini dan akan selalu begini terus".

\section{METODE}

Metode yang digunakan dalam penelitian ini adalah kualitatif dengan pendekatan studi kasus dan mengambil lokasi penelitian di Desa Bungaejaya Kecamatan Pallangga Kabupaten Gowa. Adapun yang menjadi sasaran penelitian adalah masyarakat Desa Bungaejaya dan teknik pengambilan sampel yang digunakan adalah Purposive Sampling dengan 10 orang sebagai informan dengan criteria masyarakat yang menjalankan tradisi dan tokoh adat. Teknik pengumpulan data yang digunakan adalah observasi, wawancara dan dokumentasi serta yang menjadi instrumen penelitian adalah peneliti sendiri dan ditunjang dengan beberapa instrumen pendukung seperti tape recorder, kamera dan buku catatan serta pedoman wawancara. Selanjutnya analisis data dengan jenis deskriptif yang dilakukan dengan tahap pengumpulan data, reduksi data, penyajian data dan penarikan kesimpulan. 


\section{HASIL DAN PEMBAHASAN}

\section{Keberadaan Tradisi Appakasingera' Dalle dalam Masyarakat Desa}

Masyarakat adalah orang yang hidup bersama dan menghasilkan kebudayaan dengan demikian tak ada masyarakat yang tidak mempunyai kebudayaan dan sebaliknya tidak ada kebudayaan tanpa masyarakat sebagai wadah pendukungnya karena masyarakat dan kebudayaan bagaikan dua sisi mata logam yang tidak dapat dipisahkan. Budaya yang tumbuh dan berkembang di masyarakat manusia tidak lepas dari nilai-nilai sosial budaya itu merupakan konsep yang hidup di alam pikiran sebagian besar dari warga masyarakat mengenai apa yang mereka anggap bernilai, berharga dan penting dalam hidup sehingga dapat memberi fungsi sebagai pedoman yang member arah dan orientasi kepada kehidupan warga masyarakatnya.

Manusia sebagai pencipta budaya menempatkan dirinya dalam kebiasaan-kebiasaan yang terolah secara lama menjadi sebuah tradisi, istilah tradisi ini sering diartikan sebagai adat kebiasaan yang dilakukan secara turun temurun dan masih di lakukan di masyarakat. Desa Bungaejaya adalah salah satu desa yang terletak di Kecamatan Pallangga Kabupaten Gowa, dimana mayoritas masyarakatnya adalah suku asli Makassar, yang dari generasi ke generasi keluarga mereka tinggal di daerah yang sama mulai dari nenek moyang mereka hingga ke generasi sekarang ini, walaupun terdapat suku lain seperti suku bugis maka dipastikan itu berasal dari luar. Seperti halnya desa-desa yang lain masyarakat desa Bungaejaya mempunyai beragam tradisi dan kepercayaan, yang masih mereka dijalankan sampai saat ini. Salah satunya seperti tradisi appakasingera' dalle.

Tradisi tersebut juga secara turun temurun dilakukan oleh masyarakat desa Bungaejaya, seakan telah membentuk suatu pola, ciri khas dan menjadi suatu kewajiban yang memang tidak bisa mereka tinggalkan. Dalam hal ini bahwa kebudayaan mengandung keseluruhan pengertian nilai sosial, norma sosial, ilmu pengetahuan serta keseluruhan struktur-struktur sosial, religius, dan artistik yang menjadi ciri khas suatu masyarakat. Adanya penanaman history atau sejarah awal terciptanya tradisi appakasingera' dalle dan proses pelaksanaan tradisi yang dilakukan oleh para pendahulu atau nenek moyang mereka, membuat tradisi tersebut masih dipertahankan sampai sekarang. Tradisi adalah kebiasaan sosial yang diturunkan dari satu generasi ke generasi lainnya melalui proses sosialisasi dimana manusia berusaha menyerap isi kebudayaan yang berkembang ditempat kelahirannya. Dalam hal ini, bahwa proses inilah dimana generasi tua banyak menghabiskan waktunya untuk mentransmisikan kebudayaan kepada generasi penerusnya, dan generasi penerusnya biasanya banyak sekali menerima kesan dari berbagai upaya pengajaran tersebut (Abdulsyani, 1993: 57). Dari hasil observasi dan wawancara, berikut yang di ungkapkan oleh informan yang telah diwawancarai yakni kenapa mereka tetap mempertahankan tradisi appkasingera' dalle.

Hasil temuan, yang dilakukan selama tahun 2013-2014 ada 10 informan yang mengatakan tetap mempertahankan tradisi tersebut sebab, mereka merasa nyaman ketika menjalankannya, ada rasa tentram, karena memang sudah merupakan kebiasaan yang tidak boleh ditinggalkan, sebagai bentuk penghargaan terhadap warisan para leluhur, dan adanya penanaman nilai atau history yang dilakukan oleh orangtua atau para pendahulu bahwa tradisi appakasingera' dalle baik untuk dijalankan. Menurut Weber (Johnson,1986: 220-221) menjelaskan beberapa tipe-tipe tindakan sosial, salah satunya adalah tindakan tradisional, dalam hal ini tindakan tradisional merupakan tipe tindakan sosial yang bersifat nonrasional. 
Seorang individu memperlihatkan perilaku karena kebiasaan, tanpa refleksi yang sadar atau perencanaan, perilaku seperti itu digolongkan sebagai tindakan tradisional.

Individu itu akan membenarkan atau menjelaskan tindakan itu kalau diminta, dengan hanya mengatakan bahwa dia selalu bertindak dengan cara seperti itu atau perilaku seperti itu merupakan kebiasaan baginya, apabila kelompok-kelompok atau seluruh masyarakat didominasi oleh orientasi ini, maka kebiasaan dan institusi mereka diabsahkan atau didukung oleh kebiasaan atau tradisi yang sudah lama mapam sebagai kerangka acuannya, yang diterima begitu saja tanpa persoalan. Satu-satunya pembenaran yang perlu adalah bahwa" inilah cara yang sudah dilaksanakan oleh nenek moyang kami, dan demikian pula nenek moyang mereka sebelumnya; ini adalah cara yang sudah begini dan akan selalu begini terus".

Tradisi ini merupakan sarana untuk mengaitkan masa kini dengan berorientasi kepada masa lalu dan waktu yang dapat berulang. Tradisi adalah rutinitas, namun dia adalah rutinitas yang penuh makna secara interinsik, ketimbang hanya sekedar perilaku kosong yang hanya berorientasi kepada kebiasaan semata. Upe (2010:95-99), mengungkapkan juga bahwa solidaritas sosial menujuk pada suatu keadaan hubungan antara individu dan kelompok yang berdasarkan pada perasaan moral dan kepercayaan yang dianut bersama yang diperkuat oleh pengalaman emosional bersama. Dalam masyarakat tradisional, dimana tradisi sangat kuat, kaidah-kaidah yang berlaku secara turun-temurun sama saja dari satu generasi kegenerasi berikutnya, tanpa banyak mengalami perubahan. Ukuran-ukuran yang dipakai merupakan ukuran-ukuran yang telah dipakai oleh nenek moyangnya dahulu, lagi pula kaidah-kaidah dalam masyarakat tradisional tidak begitu banyak corak ragamnya. Dalam masyarakat demikian, apalagi yang hubungannya dengan dunia luar masih kurang, daya kreasi masyarakat sedikit sehingga tindakan-tindakan yang menyimpang dari tradisi juga sangat kurang.

\section{Nilai Sosial yang Ada didalam Tradisi Appakasingera' Dalle}

Dari hasil penelitian ini malalui wawancara dan observasi terlihat bahwa selain adanya penanaman history atau searah awal dari tradisi dan proses pelaksanaanya adanya nilai yang terkandung didalam tradisi appakasingera' dalle juga merupakan alasan masyarakat tetap mempertahannya dan tetap melaksanakan tradisi tersebut secara bersama-sama, seperti nilai solidaritas, nilai kepedulian sosial, dan nilai spiritual. Nilai adalah sesuatu yang baik yang selalu diinginkan, dicita-citakan dan dianggap penting oleh seluruh manusia sebagai anggota masyarakat. Karena itu, sesuatu dikatakan memiliki nilai apabila berguna dan berharga (Sumantri, 2006:4). Menurut Polak (Setiadi, 2007:121), nilai dimaksudkan sebagai ukuran, patokan, anggapan, keyakinan yang dianut oleh orang luhur, dan baik untuk dikerjakan, dilaksanakan atau diperhatikan.

\section{SIMPULAN}

1) Masih bertahannya tradisi appakasingera' dalle atau tradisi menyalahkan lilin di Desa Bungaejaya Kecamatan Pallangga Kabupaten Gowa sampai saat ini karena masyarakat yang selalu senantiasa tetap konsisten menjaga dan mempertahankan tradisi itu dari pengaruh luar atau modernisasi yang sudah mulai masuk, yang tentunya dapat merubah pola pikir masyarakat di desa tersebut. Sejak dulu para pendahulu mereka, sejak dini memang sudah melakukan penanaman dan pemahaman kepada generasi penerus mereka atau proses sosialisasi mengenai bagaimana history atau sejarah asal muasal serta adanya nilai-nilai yang terkandung didalam tradisi tersebut yang kemudian harus mereka jaga karena semua itu demi kebaikan dan ketentraman jiwa mereka. Hal itu juga kontras 
dengan proses pelaksanaan tradisi appakasingera' dalle yang tidak pernah mengalami perubahan sampai sekarang yang tentunya selalu oleh dilaksanakan masyarakat desa Bungaejaya.

2) Adanya nilai-nilai sosial yang terkandung didalam tradisi appakasingera' dalle yaitu nilai solidaritas, nilai kepedulian sosial, dan nilai spiritual yang tentunya juga merupakan salah satu cara bagaimana masyarakat desa Bungaejaya masih mempertahankannya sampai sekarang.

Tentunya, dimana ketika Tradisi appakasingera' dalle ini dianggap oleh masyarakat pendukungnya masih bernilai positif akan terus dipertahankan, sementara jika tradisi ini dianggap tidak sesuai lagi dengan perkembangan zaman atau zaman modern, dimana kehidupan persaingan didalamnya berjalan begitu ketatnya, sehingga tradisi ini pun sudah tidak sesuai lagi tentunya akan ditinggalkan oleh pendukungnya.

Adapun implikasi akan hal ini, yaitu membawa pemahaman tentang tradisi yang bukan hanya dipahami sebagai bagian dari kebiasaan atau yang paling sederhana adalah sesuatu yang telah dilakukan untuk sejak lama dan menjadi bagian dari kehidupan suatu kelompok masyarakat, biasanya dari suatu negara, kebudayaan, waktu, atau agama yang sama.

Tradisi menentukan nilai-nilai dan moral masyarakat, karena tradisi merupakan aturanaturan tentang hal apa yang benar dan hal apa yang salah menurut masyarakat. Jadi yang menjadi hal penting dalam memahami tradisi adalah sikap atau gagasan yang berasal dari masa lalu yang dijadikan panutan bagi seseorang di masa kini.

\section{DAFTAR PUSTAKA}

Abdulsyani. 1993. Sosiologi: Skematika, Teori, dan Terapan. Jakarta: Bumi Aksara Alfian. 1985. Persepsi Masyarakat Tentang Kebudayaan. Jakarta : Gramedia.

Agustan, Andi. 2007. Filosofi Research Dalam Upaya Pengembangan Ilmu. Makassar : CV. Indobis Publisher Anggota IKAPI.

Abercrombie, Nicholas, Stephen Hill, dan Bryan S. Turner. 2010. Kamus Sosiologi. Yogyakarta: Pustaka Pelajar

Beilharz, Peter. 2005. Teori-teori Sosial Observasi Kritis terhadap Para Filosof Terkemuka. Yogyakarta : Pustaka Pelajar.

Bungin, Burhan. 2003. Analisis Data Penelitin Kualitatif. Jakarta : Raja Grafindo Persada.

Damsar. 2009. Pengantar Sosiologi Ekonomi. Jakarta : Kencana.

Jhonson, Paul, Doyle. 1986. Teori Sosiologi Klasik dan Modern. Jakarta : PT. Gramedia.

Kaplan, David. 2012. Teori Budaya. Yogyakarta : Pustaka Pelajar.

Koentjaraningrat. 2005. Pengantar Antropologi I. Jakarta : PT Rineka Cipta. 2005. Pengantar Antropologi II. Jakarta : PT Rineka Cipta. 2010. Sejarah Teori Antropologi I. Jakarta : Universitas Indonesia (UI Press).

Maram, Raga Rafael. 2007. Manusia dan Kebudayaan dalam Perspektif Ilmu Budaya. Jakarta: Rineka Cipta.

Nuraeni, Heny Gustini. 2013. Studi Budaya Indonesia. Pustaka Setia.

Narbuko, Cholid dan Abu Achmadi. 2003. Metodologi Penelitian. Jakarta : Bumi Aksara

Ranjabar, Jacobus. 2013. Sistem Sosial Budaya Indonesia. Bandung : Alfabeta. 
Ritzer, George. 2012. Teori Sosiologi Dari Sosiologi Klasik Sampai Perkembangan Terakhir Postmodern. Yogyakarta : Pustaka Pelajar.

. 2011. Sosiologi Ilmu Pengetahuan Berparadigma Ganda. Jakarta: PT Raja Grafindo Persada.

Sanderson, K. Stephen. 2010. Makro Sosiologi Sebuah Pendekatan Terhadap Realitas Sosial. Jakarta : Rajawali Pers.

Setiadi, M. Elly, dkk. 2007. Ilmu Sosial dan Budaya Dasar. Jakarta : Kencana.

Sztompka, Piotr. 2007. Sosiologi Perubahan Sosial. Yogyakarta : Prenanda Media Group.

Sumantri, Endang dan Sofyan Sauri. 2006. Konsep Dasar Pendidikan Nilai. Bandung: PT Pribumi Mekar.

Sugiyono. 2008. Metode Penelitian Kuantitatif Kualitatif dan $R \& D$. Bandung : Alfabeta.

Soekanto, Soerjono. 2002. Sosiologi Suatu Pengantar. Jakarta: Rajawali Pers.

Upe, Ambo. 2010. Tradisi Aliran dalam Sosiologi dari Filosofi Positivistik ke Post Positivistik. Jakarta: Raja Grafindo Persada.

Wulansari, C. Dewi. 2009. Sosiologi Konsep dan Teori. Bandung: PT Refika Aditama 